\title{
KONSUMSI SUPLEMEN, ASUPAN ENERGI DAN KEBUGARAN JASMANI ATLET DI PERSTUAN BULUTANGKIS KABUPATEN KUDUS
}

\author{
Tri Hastin Khusmalinda, Siti Zulaekah
}

Departemen Gizi, Fakultas Ilmu Kesehatan, Universitas Muhammadiyah Surakarta hastin.dadut@gmail.com

\begin{abstract}
Low consumption of supplements and energy intake can a decrease athlete performance because it is unable to restore stamina. The purpose of this study to determine whether there is a relationship between the consumption of supplements and energy intake of physical fitness atbletes in Badminton Association of Kudus Regency. The type of this research is observational research with cross sectional approach. The sample size used was 33 athletes $<18$ years old. Sampling was done by using simple random sampling method. Taking supplement consumption data was obtained by filling out the questionnaire. Energy intake data were obtained through questionnaire food frequency questionnaire (FFQ) semiquantitative. Physical fitness is obtained by performing a fitness test (beep test). Analysis relationship of the supplement consumption, energy intake and physical fitness using pearson product moment test. Respondents with consumption levels of supplements were often $84.8 \%$, rarely $12.1 \%$ and never $3 \%$. The results of energy intake study with severe deficit category 9.1\%, moderate deficit absent or $0 \%$, light deficit 3\%, normal 45,5\%, above requirement 42,4\%.Physical fitness levels of athletes in the category of superior $21.2 \%$, excellent $30.3 \%$, above average $24.2 \%$, an average of $15.2 \%$ and below the average of $9.1 \%$. The result of analysis of the relationship between consumption of supplement with physical fitness showed $p$ value $=0,477$ and result of analysis of energy intake relationship with physical fitness showed $p$ value $=0,535$. The conclusion of this study is that there is no relationship between supplement consumption and energy intake on physical fitness.
\end{abstract}

Keywords: consumption of supplements, energy intake, physical fitness

\section{PENDAHULUAN}

Atlet bulutangkis merupakan seorang olahragawan yang mampu berprestasi dalam cabang olahraga bulutangkis, baik di tingkat daerah, nasional maupun internasional. Tujuan dari olahraga bulutangkis adalah mendapatkan angka dan kemenangan dengan berusaha menyeberangkan dan menjatuhkan shuttlecock di daerah permainan lawan dan berusaha supaya lawan tidak dapat melakukan pukulan atau menjatuhkannya di daerah permainannya sendiri (Afifi 2015). 
Suplemen merupakan produk kesehatan yang mengandung satu atau lebih zat yang bersifat nutrisi atau obat. Suplemen dipercaya dapat meningkatkan daya tahan, mempercepat pemulihan, mengurangi massa lemak, meningkatkan masa otot atau pencapaian lain yang bertujuan meningkatkan performa atlet (Kemenkes 2014).

Asupan zat gizi merupakan salah satu faktor penentu pada kebugaran. Asupan gizi yang baik akan menghasilkan energi yang cukup pula, karena energi dibutuhkan oleh tubuh untuk melakukan aktivitas sehari-hari (Putri 2015).

Kebugaran jasmani adalah suatu kemampuan tubuh yang berfungsi secara efisien dan efektif (Corbin 2010). Kebugaran jasmani dipengaruhi oleh berbagai macam faktor, diantaranya sistem respirasi, kadar hemoglobin, sistem otot, sistem metabolisme, dan status gizi, serta tergantung pada umur, jenis kelamin, program aktivitas jasmani, dan latihan olahraga (Sarwono 2008). Selain itu, terdapat makanan dan minuman yang dikonsumsi akan meningkatkan performa selama aktivitas fisik seperti konsumsi vitamin, mineral ataupun berupa suplementasi (Magfirah et al. 2013).

Tujuan penelitian ini yaitu mendiskripsikan konsumsi suplemen, asupan energi, dan kebugaran jasmani atlet bulutangkis, serta menganalisis hubungan konsumsi suplemen dan asupan energi terhadap kebugaran jasmani atlet bulutangkis.

\section{METODE}

Penelitian ini merupakan penelitian observasional dengan metode pendekatan cross sectional. Pengambilan sampel menggunakan teknik simple random sampling yaitu atlet bulutangkis di Kabupaten Kudus yang memenuhi kriteria inklusi yang meliputi atlet bulutangkis usia $<18$ tahun, atlet sedang dalam masa latihan, atlet tidak dalam keadaan cidera, dan atlet tidak dalam masa kompetisi. Kemudian diambil secara acak sederhana, dengan jumlah sampel sebanyak 33 atlet. Penelitian ini dilakukan pada bulan April sampai dengan Desember 2016.

Jenis data dalam penelitian ini adalah data kuantitatif yang meliputi konsumsi suplemen, asupan energi, dan kebugaran jasmani. Sumber data ini terdiri dari data primer dan sekunder. Cara pengambilan data primer yaitu data identitas responden dengan melalukan wawancara, pengukuran berat badan dan tinggi badan, data konsumsi suplemen diperoleh dengan mengisi kuesioner. Data asupan energi diperoleh dari kuesioner food frequency questionaire (FFQ) semi-quantitative kemudian di-input pada aplikasi Nutrisurvey dan SPSS versi 16 for windows. Data kebugaran jasmani diperoleh dengan melakukan tes kebugaran jasmani (beep test). Beep Test merupakan salah satu metode untuk mengetahui daya tahan aerobik secara maksimal. Prosedur pelaksanaannnya 
dapat dilakukan di dalam maupun di luar ruangan, dilakukan dalam satu waktu (7-8 atlet) dan hasil pengukuran bisa langsung diperoleh yaitu dengan cara berlari bolak-balik (start dan finish yang sudah ditentukan) pada lapangan yang berukuran panjang 20 meter dan lebar 1 meter, serta mengikuti bunyi yang telah ditentukan dengan peningkatan level kecepatan pada setiap tanda beep. Data sekunder seperti hasil pengukuran kebugaran jasmani dan monografi daerah klub bulutangkis diperoleh dengan cara wawancara.

Hasil analisis kenormalan data menggunakan uji kolmogorof smirnov, dan menunjukkan semua data berdistribusi normal, sehingga digunakan uji analisis hubungan antara konsumsi suplemen dan asupan energi terhadap kebugaran jasmani menggunakan uji pearson product moment.

\section{Karakteristik Subjek Penelitian \\ HASIL DAN PEMBAHASAN}

Persatuan Bulutangkis Seluruh Indonesia (PBSI) banyak memberikan kontribusi dan dukungan pada perkembangan dunia olahraga bulutangkis di Kabupaten Kudus. Di Kabupaten Kudus terdapat pembinaan klub bulutangkis yang tidak sedikit dimana pada tahun 2013 terdapat 50 klub dan setiap tahunnya mengalami peningkatan. PBSI-pun juga ikut berperan dalam pembinaan klub di Kabupaten Kudus. Kontribusi PBSI berupa penyediaan sarana dan prasarana, serta pembiayaan terhadap klub.

Subjek dalam penelitian ini adalah atlet bulutangkis di Kabupaten Kudus yang berjumlah 33 atlet. Subjek penelitian lebih banyak laki-laki dengan persentase 51,5\%, sedangkan perempuan 48,5\%. Tingkat frekuensi konsumsi suplemen menururt Aisyah (2006) dalam Magfirah et al. (2013) dikategorikan sering apabila frekuensi konsumsi 4-7 kali seminggu, jarang apabila frekusnsi konsumsi 1-3 kali seminggu dan tidak pernah apabila frekuensi suplemen $<2$ minggu sekali. Hasil data tingkat frekuensi konsumsi suplemen menunjukkan bahwa kategori sering lebih banyak yaitu dengan persentase 84,8\% sedangkan yang paling sedikit adalah kategori tidak pernah dengan persentase 3,0\%. Subjek sering mengkonsumsi suplemen selama latihan memang sering terjadi, karena hampir semua atlet beranggapan bahwa suplemen dapat meningkatkan stamina dan kebugaran selama latihan maupun pertandingan.

Kecukupan persentase asupan energi menurut Depkes RI (1996) dalam Anggraeni (2012) menyatakan bahwa defisit berat $<70 \%$, defisit sedang $70-79 \%$, defisit ringan 80-89\%, normal 90-119\%, diatas kebutuhan atau lebih $>120 \%$. Hasil data asupan energi menunjukkan bahwa atlet dengan kategori asupan normal lebih banyak yaitu 45,5\% dibandingkan atlet dengan asupan yang defisit dan di atas kebutuhan. Atlet dengan kategori defisit berat yaitu sebanyak 9,1\%, atlet dengan defisit sedang tidak ada atau $0 \%$, atlet dengan 
defisit ringan yaitu 3\% dan atlet dengan kategori di atas kebutuhan sebanyak $42,4 \%$.

Pengukuran kebugaran jasmani dikategorikan menggunakan tabel $\mathrm{VO}_{2}$ Maks menurut PB Djarum yang di bedakan berdasarkan jenis kelamin dan umur terdiri dari 6 kategori. Hasil data kebugaran jasmani menunjukkan bahwa atlet dengan kategori excellent lebih banyak dibandingkan dengan kategori lainnya yaitu 30,3\%. Kategori di bawah rata-rata dengan persentase terendah yaitu 9,1\%. Gambaran karakteristik subjek dapat dilihat pada Tabel 1 di bawah ini.

Tabel 1. Distribusi Karakteristik Subjek berdasarkan jenis kelamin, frekuensi konsumsi, dan kebugaran jasmani

\begin{tabular}{ccc}
\hline Karakteristik & Jumlah (n) & Persentase (\%) \\
\hline Jenis Kelamin & & \\
Laki-laki & 17 & 51,5 \\
Perempuan & 16 & 48,5 \\
Frekuensi Konsumsi & & \\
Suplemen & 28 & 84,8 \\
Sering & 4 & 12,1 \\
Jarang & 1 & 3,0 \\
Tidak Pernah & & \\
Tingkat Asupan Energi & 3 & 9,1 \\
Defisit Berat & 0 & 0,0 \\
Defisit Sedang & 1 & 3,0 \\
Defisit Ringan & 15 & 45,5 \\
Normal & 14 & 42,4 \\
Di Atas Kebutuhan & & \\
Kebugaran Jasmani & 3 & 9,1 \\
Di bawah rata-rata & 5 & 15,2 \\
Rata-rata & 8 & 24,2 \\
Di atas rata-rata & 10 & 30,3 \\
Excellent & 7 & 21,2 \\
Superior & &
\end{tabular}

\section{Hubungan Konsumsi Suplemen dengan Kebugaran Jasmani}

Hasil analisis hubungan konsumsi suplemen dengan tingkat kebugaran jasmani menggunakan uji Pearson Product Moment yang menunjukkan nilai $\mathrm{p}=$ 0,477. Berdasarkan hasil analisis didapatkan nilai $\mathrm{p} \geq 0,05$ (Tabel 2), dengan demikian Ho diterima sehingga tidak ada hubungan antara konsumsi suplemen dengan tingkat kebugaran jasmani.

\begin{tabular}{ccccc}
\hline Variabel & Mean \pm SD & Minimum & Maksimum & p* $^{*}$ \\
\hline Konsumsi Suplemen & $42.61 \pm 14.90$ & 12 & 60 & 0,477 \\
Kebugaran Jasmani & $48.78 \pm 7.58$ & 34.70 & 62 & \\
\hline
\end{tabular}


Penelitian ini sesuai dengan Sugiarto (2012) yang menyatakan bahwa tidak ada hubungan antara asupan suplemen dengan tingkat kebugaran. Menurut Widodo (2012) yang melakukan tes keterampilan pada pemain bulutangkis dengan mengkonsumsi suplemen dan tidak mengkonsumsi suplemen dengan hasil rata-rata yang cukup tinggi. Kesimpulan yang diperoleh dari penelitian tersebut yaitu tidak ada pengaruh konsumsi suplemen dengan keterampilan pukulan smash dalam permainan bulutangkis pada PB Sehat Semarang. Perbedaan pada hasil keterampilan pukulan smash bukan karena banyaknya konsumsi suplemen, melainkan dari keterampilan sampelnya. Selain itu terdapat beberapa faktor yang mempengaruhi kebugaran antara lain pendapatan, keturunan, umur, asal keluarga, aktivitas sehari-hari, serta pengaruh lingkungan sekitar (mengacu pada lifestyle) (Corbin 2010).

\section{Hubungan Asupan Energi dengan Kebugaran Jasmani}

Hasil analisis hubungan asupan energi dengan kebugaran jasmani menggunakan uji Pearson Product Moment yang menunjukkan nilai $\mathrm{p}=0,535$, sehingga $\mathrm{p} \geq 0,05$, dengan demikian Ho diterima yang berarti tidak ada hubungan antara asupan energi dengan kebugaran jasmani.

\section{Hubungan Asupan Energi dengan Kebugaran Jasmani}

\begin{tabular}{ccccc}
\hline Variabel & Mean \pm SD & Minimum & Maksimum & $\mathbf{p}^{*}$ \\
\hline Asupan energi & $115.18 \pm 25.93$ & 68 & 188 & 0,535 \\
Kebugaran Jasmani & $48.78 \pm 7.58$ & 34.70 & 62 & \\
\hline
\end{tabular}

Hasil penelitian ini sesuai dengan Dewi dan Kuswary (2013) yang menyebutkan bahwa tidak ada hubungan antara asupan energi dengan kebugaran atlet bulutangkis. Hasil penelitian Pertiwi (2012) menyatakan bahwa asupan energi tidak berpengaruh terhadap daya tahan jantung paru atlet sepak bola. Hal ini terjadi karena kemapuan tubuh menggunakan oksigen secara maksimal dapat dipengaruhi oleh faktor fisik (Suparmin 2015). Ketika berolahraga otot akan berkontraksi sehingga menimbulkan adanya gerakan tubuh (Primana 2000). Menurut Pertiwi (2012) pada penelitinnya dengan latihan aerobik yang dilakukan secara teratur akan menyebabkan adanya peningkatan nilai kebugaran jasmani. Hal ini disebabkan karena ketika melakukan latihan tersebut suplai oksigen ke otot meningkat sehingga memberikan kemampuan atlet untuk melakukan olahraga dengan durasi yang cukup lama dan lebih besar dalam penggunaan oksigen secara maksimal. 


\section{KESIMPULAN}

Berdasarkan hasil penelitian yang telah dilakukan, dapat disimpulkan bahwa sebagian besar atlet sering mengonsumsi suplemen dan memiliki tingkat kecukupan energi normal. Tingkat kebugaran jasmani atlet sebagian besar memiliki kategori excellent. Tidak ada hubungan konsumsi suplemen dengan tingkat kebugaran jasmani atlet di Persatuan Bulutangkis Kabupaten Kudus. Tidak ada hubungan asupan energi dengan tingkat kebugaran jasmani atlet di Persatuan Bulutangkis Kabupaten Kudus.

\section{DAFTAR PUSTAKA}

Anggraeni AC. 2012. Nutritional Care Process. Graha Ilmu. Yogyakarta.

Afifi SN. 2015. Kondisi Fisik. Atlet Bulutangkis Klub Djarum Dan Faktor Yang Mempengarubi. Skripsi. Jurusan Pendidikan Kepelatihan Olahraga. Universitas Negeri Semarang. Semarang.

Corbin C, Lindsey R, Welk G, Corbin W. 2010. Concepts of Fitness and Wellness: A Comprehensive Lifestyle Approach, 4/e. McGraw-Hill Global Education Holdings, LLC. Online Learning Center.

Dewi EK dan Kuswary M. 2013. Hubungan Asupan Zat Gizi Makro dan Status Gizi Terhadap Kebugaran Atlet Bulutangkis Jaya Raya Pada Atlet Laki-Laki

Dan Perempuan di Asrama Atlet Ragunan Tabun 2013. Nutrire Diaita. Volume 5 Nomor 2.

Kemenkes RI. 2014. Pedoman Gizi Olahraga Prestasi. Jakarta.

Magfirah F, Wijanarka A, dan Arovah NI. 2013. Hubungan Tingkat Pengetahuan Pengetahuan Gizi Olahraga, Frekuensi Konsumsi Suplemen, dan Status Gizi dengan Kebugaran Jasmani Atlet di Klub Sepakbola PSIM Yogyakarta. Vol. 8, No. 1. Edisi ketiga. ISSN: 1907-3887.

Pertiwi AB dan Murbawani EA. 2012. Pengarub Asupan Makanan (Energi, Karbohidrat, Protein dn Lemak) terhadap Daya Tahan Jantung Paru $\left(\mathrm{VO}_{2}\right.$ Maks) Atlet Sepak Bola. Artikel Penelitian. Universitas Diponegoro. Semarang.

Putri H. 2015. Faktor yang Berbubungan dengan Kebugaran Mahasiswa Program Studi Kesehatan Masyarakat UIN Syarif Hidayatullah Jakarta. Skripsi. Universitas Islam Negeri Syarif Hidayatullah. Jakarta.

Primana DA. 2000. Pemenuhan Energi pada Olahraga. Pedoman Gizi Olahraga untuk Prestasi. Jakarta. Departemen Kesehatan dan Kesejahteraan Sosial RI Direktorat Gizi Masyarakat.

Sarwono. 2008. Hubungan Kebugaran Jasmani Mahasiswa dengan Indeks Masa Tubuh dan Kadar Haemoglobin. Paedogogia.11(2):124-135. 
Sugiarto. 2012. Hubungan Asupan Energi, Protein dan Suplemen dengan Tingkat Kebugaran. Jurnal Media Ilmu Keolahragaan Indonesia. Vol. 2 Edisi 2. ISSN: 2088-6802.

Suparmin M. (2015). Identifikasi Faktor Fisik Atlet Cabang Bulutangkis. Jurnal Imiah SPIRIT. ISSN; 1411-8319 Vol. 15 No. 1.

Widodo GSN. 2008. Pengaruh Minuman Suplemen "Pocari Sweat" antara Sebelum dan Sesudab Minum Suplemen terhadap Keterampilan Pukulan Smash dalam Permainan Bulutangkis Pemain Putra PB.Sehat Semarang. Skripsi. Universitas Negeri Semarang. Semarang. 